\title{
Addressing Duty of Loyalty Parameters in Partnership Agreements: The More is More Approach
}

\author{
By Thomas P. Corbin Jr.
}

In drafting a partnership agreement, a clause addressing duty of loyalty issues is a necessity for modern partnerships operating under limited or general partnership laws. In fact, the entire point of forming a limited partnership is the recognition of the limited involvement of one of the partners or perhaps more appropriate, the extra-curricular enterprises of each of the partners. In modern operations, it is becoming more common for individuals to be involved in multiple business entities and as such, conflict of interests and breaches of the traditional and basic rules on duty of loyalty such as those owed by one partner to another can be nuanced and situational. This may include but not be limited to affiliated or self-interested transactions. State statutes and case law reaffirm the rule that the duty of loyalty from one partner to another cannot be negotiated completely away however, the point of this construct is to elaborate on best practices of attorneys in the drafting of general and limited partnership agreements. In those agreements a complete review of partners extra-partnership endeavours need to be reviewed and then clarified for the protection of all partners. Liabilities remain enforced but the parameters of what those liabilities are would lead to better constructed partnership agreements for the operation of the partnership and the welfare of the partners. This review and documentation by counsel drafting general and limited partnership agreements are now of paramount significance.

Keywords: Partnership Formation, Duty of Loyalty; Partnership Agreements; Client Counselling.

\section{Introduction: General Rule on Duty of Loyalty in General/Limited Partnerships}

The general rule regarding the fiduciary duty of loyalty in a partnership is that the partners are to put the success and interests of the partnership above their own personal and other business interests. Partners are considered both "a principal and an agent, both a trustee and a beneficiary" with regards to the property, operation, benefits and obligations of the partnership. These concepts are nothing new but the modern operations of business and the law governing situation where partners are engaged in multiple business activities within and outside of the business entity are growing in consideration. Partners should avoid conflict of interests between their partnership duties and activities and their own personal and extra-curricular business activities, including but not limited to other business entities and personal activities. As a part of the duty

\footnotetext{
*Associate Professor, American University in Dubai, Dubai, UAE. Email: tcorbin@aud.edu. ${ }^{1}$ Crane \& Bromberg (1968) at 389.
} 
of loyalty, a partner must hold the partnership's property in trust for the benefit of all the partners and not use the partnership property for personal or nonpartnership advantage.

"For example, a general partnership may own an office building, but a general partner should not dispose of that partnership asset for his or her individual economic gain to the detriment of the partnership. In some instances, you may be allowed to obtain an individual benefit from partnership assets after full disclosure to and prior approval from the other partners."

Generally speaking, a partner's fiduciary duties may not be waived or eliminated in partnership agreements and in fulfilling those fiduciary duties, each partner must act consistently with the obligations of good faith and fair dealing. "Good Faith" and "Fair Dealing" has been defined by courts as covenants owed to each partners by the other and further considered as "the person undertaking an action must believe that the determinations or other action is in the best interests of the partnership;" and "consistency with the parties' agreement and its purpose", respectively. ${ }^{4}$

It should also be noted that partners are permitted to pursue their own nonpartnership related interests without automatically violating their fiduciary duties. ${ }^{5}$ The most important aspect in determining if there was a breach of the duty of loyalty is a question of disclosure to other partners. However, in Dieckman $v$. Regency, a 2017 decision, ${ }^{6}$ the Delaware Court of Chancery decided to "again confirmed that the contractual arrangements set forth in a limited partnership agreement will define the respective rights and obligations of the partners, including with respect to the general partner's fiduciary duties (and related duty of disclosure) in connection with affiliated transactions." "In limited partnerships, some jurisdictions, such as Delaware, have allowed for the parties to "expand or restrict fiduciary duties," but "they could not fully eliminate them." ${ }^{8}$ Of course, this only becomes of large concern when limited partners take either a managerial or controlling stake in the partnership. ${ }^{9}$ It would also be of potential concern where the limited or silent partner's contributions are such that they overshadow every decision made by the day-to-day operators and the general partners.

\footnotetext{
${ }^{2}$ Fiduciary Duties in Partnerships, NOLO Legal Encyclopedia, Legal Topics, Business Formations. ${ }^{3}$ See generally, Uniform Partnership Act, 103(b) and 404(d).

${ }^{4}$ Reid (2014), Allen v. El Paso Pipeline GP Co., L.L.C., C.A. No. 7520-VCL (Del. Ch. May 19 2014) (Laster, V.C.) and Feeley v. NHAOCG, LLC, 62 A.3d 649, 664 (Del. Ch. 2012) (citing Arnold v. Soc'y for Savs. Bancorp, Inc. 678 A.2d 533, 541-42 (Del. 1996).

${ }^{5}$ Uniform Partnership Act, 404(e).

${ }^{6}$ Diechman v. Regency, GP LP, et al., No. 208, 2016 (Del. Jan. 20, 2017)

${ }^{7}$ Fried Frank (2016).

${ }^{8}$ See Gotham Partners, L.P. v. Hallwood Realty Partners, L.P., 817 A.2d 160, 167 (Del. 2002) and Lewis (2013).

${ }^{9}$ Fiduciary Duties in Partnerships, NOLO Legal Encyclopedia, Legal Topics, Business Formations.
} 


\section{Analysis of State Partnership Acts in Comparison to the Standard Uniform Partnership Act and the Revised Uniform Partnership Act}

The term duty of loyalty has scant appearance in the Uniformed Partnership Act and an understanding of what can be "interpreted" as duties of loyalty can be found in a "number" of places in the Uniformed Partnership Act. ${ }^{10}$ This can be contrasted, for example, with the Maryland Revised Uniform Partnership Act Subtitle $4^{11}$ where it clearly outlines the Duty of Loyalty as

"A partner's duty of loyalty to the partnership and the other partners is limited to the following:

To Account to the partnership and hold as trustee for it any property, profit or benefit derived by the partner in the conduct and winding up of the partnership or derived from the use by the partner or partnership property, including appropriation of a partnership opportunity;

(1) To refrain from dealing with the partnership in the conduct or winding up of the partnership business as or on behalf of a party having an interest adverse to the partnership; and

(2)To refrain from competing with the partnership in the conduct of the partnership business before the dissolution of the partnership."

As always, the election of where to file business operation paperwork is a strategic concern for parties, but a significant concern for the counselling clients in these regards should be considered. Protection of the client's well-being and interests in forming a business entity should be examined from the broad construct of avoiding as many potential hazards as possible. As such addressing duty of loyalty issues in a limited or general partnership would need to consider the statutory and case law review of the concept. Projections of potential hazards would then be paired within these confines to produce a protective arrangement leading to fruitful operations in the future.

The Michigan's Uniform Partnership Act, ${ }^{13}$ like other jurisdictions, borrows heavily from model language but does not directly comment too greatly on what would constitute a duty of loyalty breach for partners within the partnership. In a General Partnership, also known in Michigan as a "Copartnership", ${ }^{14}$ partners owe duties to one another as agents ${ }^{15}$ and fiduciaries. ${ }^{16}$ As such, agents acting outside of their stated duties or failing to hold in trust benefits derived to the partnership and all the partners is cause for dissolution by court decree. ${ }^{17}$ Keeping this mind,

\footnotetext{
${ }^{10}$ Weidner \& Larson (1993). Also see generally Uniform Partnership Act $§ 18$.

${ }^{11}$ Maryland Code: Corporations and Associations, Title 9A-Maryland Revised Uniform Partnership Act Subtitle 4-Relations of partners to Each Other and to Partnership, Section 404General Standards of Partner's Conduct. (2010).

${ }^{12}$ Weidner \& Larson (1993).

${ }^{13}$ Michigan Uniform Partnership Act 72 of 1917, Section 449.18-23.

${ }^{14}$ Frances.

${ }^{15}$ Michigan Uniform Partnership Act 72 of 1917, Sections 449.4(3) and 449.9.

${ }^{16}$ Michigan Uniform Partnership Act 72 of 1917, Section 449.21.

${ }^{17}$ See Michigan Uniform Partnership Act 72 of 1917, Sections 449.29-44 generally and Section 449.32(1)(d) \& (f) which specifically states with regards to court ordered dissolution that: "A
} 
from a client-counseling scenario, an attorney would in aiding in the original formation of a partnership, and purposefully drafting a general partnership agreement, would need to take time to explain agency and fiduciary concepts to the clients and potential partners. What would ultimately need to also be undertaken is clearly exploring with the clients any potential situation where a copartner ${ }^{18}$ would have potential conflicts of interest including but not limited to self-dealing transactions or duty of loyalty breaches listed and documented clearly in the aforementioned partnership agreement.

What becomes notable at this juncture, is where a general partnership ends and a limited partnership begins. The Michigan Revised Uniform Limited Partnership Act provides for limited partnerships in the jurisdiction of Michigan. ${ }^{19}$ Limited partners generally do not owe fiduciary duties, but they assume fiduciary duties if they take an active role in the management of the partnership. ${ }^{20}$ What gives pause is what would constitute an active role in the management of the partnership and whether an issue of a self-interested transaction or an encouragement to have the partnership to conduct business with the limited partners" other business enterprises constitute an "active role" in the partnership management? General rules, including those in Michigan and Delaware, ${ }^{21}$ all indicate that limited partners have not liability beyond their investment. In a perfect environment, limited partners in a LLP would have no say or "control"22 on the day-to day operations of the partnership. However, this might not usually be the case when and where a limited partners takes an interest or in instances where the financial contribution to the enterprise is of such a size and shape that it would be a specter resting over all decisions being made by the general partners.

The fiduciary duty of loyalty is an important construct in the formation, operation and ultimately disassociation of a partnership. The Michigan Supreme Court has defined a fiduciary relationship as "a relationship in which one person is under a duty to act for the benefit of the other on matters within the scope of the relationship." As pointed out in Banker \& Brisebais Co v John C. Maddox, CPA, unpublished opinion per curiam of the Michigan Court of Appeals, issued April 29, 2014 (Docket No. 310993):

"Fiduciary relationships arise (1) where one reposes trust in the faithful integrity of another, who gains influence over that person; (2) where one assumes control and responsibility over another; (3) where one has a duty to act for or advise another on matters within the scope of the relationship; and (4) when the specific relationship has

partner willfully or persistently commits a breach of the partnership agreement, or otherwise so conducts himself in a manner relating to the partnership business that it is not reasonably practicable to carry on the business in the partnership with him" and "Other circumstances render a dissolution equitable."

${ }^{18}$ Michigan Uniform Partnership Act 72 of 1917, Section 449.18-23.

${ }^{19}$ Michigan Revised Uniform Limited Partnership Act 213 of 1982, Section 449.1403.

${ }^{20}$ Feeley v. NHAOCG, LLC, 62 A.3d 649, 662 (Del. Ch. 2012) (citing Cantor Fitzgerald, L.P. v. Cantor, No. 16297, 2000 WL 307370, at*22 (Del. Ch. Mar. 13, 2000).

${ }^{21}$ Michigan Revised Uniform Limited Partnership Act 213 of 1982, Section 449.1403.

${ }^{22}$ See, e.g., BSA Mull, No. 310989, at *10 (applying Michigan shareholder oppression law to assist the court in understanding the LLCA's definition of "willfully unfair and oppressive conduct.") See also Mantese \& Williamson (2014). 
traditionally been recognized as involving fiduciary duties, such as between lawyer and client., 23

Legal constructs have allowed for a limiting of loyalty liability in limited liability partnerships and limited partnerships. Strong counseling on the issue would need to be a priority for attorneys aiding in the formation of a partnership agreement. Especially if the attorney is counseling the potential general partner in a limited partnership arrangement. Limited partners may have only given an infusion of cash to the partnership enterprise and assumed no day-to-day management or decision-making prowess. In those instances a firm argument of limits on duty of liabilities relevant. But again, in many cases the limited or silent partner's infusion of cash or buy-in to the partnership maybe of such a large sum, that the general partner maybe inclined to take decision making on management issues to the silent partner or even completely decide against proper actions due to fear of upsetting the silent partner. This might then result in a withdraw of the sum buy-in. It can thus be argued that first, a silent or limited partners may not have a defined duty of loyalty to a partnership but their influence may not be denied. Secondly, based on this influence, the level of control or the specter of control could influence the decision making of the partnership towards decision that may not be in the best interest of the other partners. This reality is not necessarily always present or even something that the legislature has any business manipulating. The freedom to contract is forever sacrosanct. ${ }^{24}$ Also, the formation of a partnership is at its very nature a contractual agreement between the partners. ${ }^{25}$ As such the parties are free to contract for and contract away whatever rights and liabilities they have in their partnership agreement. In his 2004 Suffolk Law Review Article, Professor Ribstein argues that that the "ULPA 2001 restrictions on contracting regarding fiduciary duties are seriously misguided because they are based on a fundamental misunderstanding of the special nature and functions of the limited partnership form". ${ }^{26}$ A greater analysis of the logic and reasoning follows in the article, but the overarching reality is true that the freedom of contracting in partnership agreements should be rarely narrowed by legislation, however attorneys counseling clients should have a free range to limit partners, both general and limited in their drafting of the partnership agreement. Government has no duty or right to second-guess the decisions made by the contracting parties short of capacity deficiencies, legal requirements or instances of unconscionability. The larger point however, is that in the protection of the client's rights, an attorney in counseling the formation of the partnership agreement needs to advise the parties about potential conflict of interests or potential issues that may arise among the parties. In the case of silent or limited partners, general partners would need to clearly understand what limited partners may be able to engage in any and all extra-curricular activity that may be converse

\footnotetext{
${ }^{23}$ Mantese \& Willaimson (2014) quoting from Banker \& Brisebais Co., v. John v. Maddo, CPA, unpublished opinion per curium of the Court of Appeals, issued April 29, 2014 (Docket No. 310993 ) "accountant-client relationship is not a traditionally recognized fiduciary relationship".

${ }^{24}$ Bernstein (2008).

${ }^{25}$ Mayer, Warner, Siedel, Lieberman \& Martina (2012).

${ }^{26}$ Ribstein (2004).
} 
to the general partnership. Also, the general partners would need to be advised to always place themselves in a position where their decision making would never be compromised by the weight of the silent partners contribution to the enterprise or their conduct outside of the partnership confines. Strong counseling on potential conflict issues would act as a counter weight against the necessary but still problematic gaps in protecting general partners from the limited responsibility of limited or silent partners.

\section{Partnership Agreements}

Partnership agreements are one of the most underrated forms of risk management and avoidance in business operations. General partnership agreement often include language on basic structure, capital contributions, sharing of profits, management and control, accounting controls, dissociation and dissolution agreements and arbitration of disputes of any of the above. ${ }^{27}$ In the formation of a partnership agreement, it is a reality that the human condition is forever present. Most likely, the constructing of a partnership in the beginning stages is one where the full range of cooperation, support and promotion of each of the partners is in play. All the partners likely operate under the belief that the other partner is as committed as they are and their expectations of the enterprise and the cooperating partners have only the upside in sight. But reality usually sets in after operation begins. Rarely do things work out as well as people's expectations. A cool and dispassionate viewpoint would best serve the enterprise in reviewing the intent, capabilities and contributing factors of the parties and then documenting them into a partnership agreement. As mentioned above, a complete and forethought focused partnership agreement would go a long way towards protecting clients in the formation, operation and if necessary dissociation events of a partnership if they included a concise language on fiduciary duties. It is well established that a partner cannot compete against his partnership, nor accept secret profits unless he obtains permission from the other partners. ${ }^{28}$ Partnership formation agreements very often define exactly what conduct would constitute competition against the environment. The Revised Partnership Act, for example, indicates that one cannot

"eliminate the duty of loyalty under Section 404(b) or 603(b)(3), but: (i) the partnership agreement may identify specific types or categories of activities that do not violate the duty of loyalty, if not manifestly unreasonable $[\ldots]^{329}$

Consider for example, an agreement concerning a partnership of an auditing firm may point out that no partner may provide, including pro bono, auditing services except on behalf of the organised partnership. ${ }^{30}$ This clause or agreement in a partnership agreement is not unlike non-competition clauses in employment

\footnotetext{
${ }^{27}$ Clarkson, Miller \& Cross (2015).

${ }^{28}$ Mallor, Barnes, Langvardt, Prenkert \& McCrory (2016) at 1034.

${ }^{29}$ See Ribstein (2004) at fn. 4 discussing the Revised Partnership Act.

${ }^{30}$ Ribstein (2004).
} 
contracts. The general rule of non-competition among general partners is rather simple to understand and enforce. What is more problematic and thus significant for the counselling of clients planning to be a general partner interested in taking on limited or silent partners is that limited partner do not owe a fiduciary duty to the limited partnership or the other partners in solely being a limited partner. As such a limited partner can invest in an auditing partnership, as exampled above, but then also invest in the across town rival with little to no recourse for the original partnership that was invested in. Limited partners are expected to hold the standard of good faith and fair dealing with a limited partnership and as such are expected to disclose significant issues that may impact the partnership. ${ }^{31}$ But because many jurisdictions do not require much, if any agreement to be filed, ${ }^{32}$ the formation of a general partnership is simply a matter of intent between the parties. In a Limited Partnership, the creation of the partnership must be created "only by complying with applicable state statute". ${ }^{33}$ Without the protections of a partnership agreement partners often enter the enterprises with the best of intentions but without fully realizing the potential pitfalls. There are endless instances where the human condition can lead to ruin between partners but a thorough partnership agreement, signed and executed between the partners can minimize many of the area of potential discontent. With regards to the duty of loyalty issues, relying on the general rule as stated above and not fully documenting existing and recognised conflicts of interest that might arise due to extra-partnership activities by the partners themselves. From a legal counselling standpoint, attorneys would be hard-pressed to not suggest a partnership agreement between the parties but including provisions in an agreement fully underlining potential conflicts of interest and how the parties can recognise and avoid the conflicts is simple best practices for client management. A rigorous interviewing of potential general partners and potential limited partners with regards to their expectations of the partnership, the other partners and the knowledge of what the other partners' extra partnership activities is an essential part of drafting process. No stone, proverbial or otherwise, should be left unturned in determining what real, potential or possible conflict of interest or duty of loyalty breaches may arise in the operation of the partnership. Again, it should be stressed that duty of loyalty cannot be out right negated through a partnership agreement. However, a clear outlining of what the partners would see as a duty of loyalty issue between them should be fully outlined and be instituted into the agreement and used as a guideline through the business' operations and then also as a tool for avoidance of litigation in the future. Consider finally that decisions such as the Dieckman v. Regency decision indicates that

"partnership agreements can eliminate all general partner fiduciary duties with respect to affiliated transactions.",34.

\footnotetext{
${ }^{31}$ Ribstein (2004) at 1082.

${ }^{32}$ Frances, and See also Michigan Uniform Partnership Act 72 of 1917 Section 449.7.

${ }^{33}$ Ribstein (2004) at 1078. See also Uniform Partnership Act, last revised 2001.

${ }^{34}$ Fried Frank (2016).
} 
Understanding this then re-underlines the need of attorneys in client counselling to tell make sure the clients understand that there may be instances of potential conflict of interest. Documenting them ahead of time allows for the client to prepare for them and ultimately factor these possibilities into whether going into a partnership with a potential general or limited partner is worth the risk of having their actions harm the partnership or the other partners.

\section{Practice Points and Sample Language for Duty of Loyalty Clause in Partnership Agreement}

Some sample partnership agreements already include a Duty of Loyalty clause. ${ }^{35}$ It is also noted that agreements can specify acts that the partners agree will violate a fiduciary duty and the key remains simply whether the partner, in the pursuit of their non-partnership endeavours, discloses to other partners the actions or conduct. But leaving too much discretion up to the "good conduct" or "faith based" 36 approach of the partners is problematic and best practices of attorneys should be to create for clients and more sturdy partnership agreement that constitutes potential duty of loyalty breaches. As noted above, RUPA ${ }^{37}$ does indicate that partners cannot "eliminate the duty of loyalty, although the partners may identify specific types or categories of activities that do not violate the duty, if not manifestly unreasonable". It is the second part ${ }^{38}$ of that statement, regarding the identification of types or categories of activities that attorneys in their counselling of clients and the drafting of partnership agreements need to take a strong review of in modern partnership formation and performance. This again, is due to the nature of the modern trend of partners being involved in a multitude of enterprises.

Successful general partnership agreements will need to take into the account and address any, and all extra-partnership endeavours that may endanger the partnership and limited partnership agreements should take care with regards to the extent to which general partners obligations are being restricted and how this would affect limited partners. Such provisions would include attention to the elimination of fiduciary duties, so called "safe harbour provisions" 39 for affiliated transactions, dispute resolutions of potential affiliated transactions such as a conflicts committee and the limits of the disclosure obligations.

An aggressive pursuit of understanding all of the potential partners' interests in the formation or addition to a general or limited partnership is the best tactical advice for attorneys aiding in the drafting of partnership agreements. Asking the hard questions and presenting the difficult 'what if' situations to the partners is part-and-parcel of zealous representation. If an attorney sees a potential

\footnotetext{
${ }^{35}$ Law Depot, Free Partnership Agreement, Create Your Partnership Agreement-Place of Business: Michigan.

${ }^{36}$ See generally, Uniform Partnership Act, 103(b) and 404(d).

${ }^{37}$ Uniform Partnership Act, Section 103(a).

${ }^{38}$ Weidner \& Larson (1993).

${ }^{39}$ Fried Frank (2016).
} 
conflict of interest, self-dealing issue or any other duty of loyalty breach, the attorney will need to bring it to the client's attention. Once discussed, the clients can decide how to minimize the potential impact of the duty of loyalty issue and then document it a partnership agreement. This foresight will also make the management of the general or limited partnership more manageable as well. Known expectations are always more manageable than unknown variables. ${ }^{40}$

Even understanding the basic rule that limited partners are not held to the same level of fiduciary duty ${ }^{41}$ as general partners, it behoves an advising attorney to flush out completely any and all potential issues that may arise. Though it is true that the limited partner may not ultimately be held liable or responsible in a potential duty of loyalty claim, a general partner should be fully advised as to this reality and protected against to the fullest extent in the partnership agreement. This can only be accomplished by ferreting out the potential issues through aggressive questioning of the potential partners about their current and future activities. Undoubtable, as partnerships are subject to the constant human condition of expectations being high in the beginning may create a chilling effect on formation as realization about traits and expectations of other partners come into full view. It can be recommended that a partnership clause, created after a full and frank conversation with potential partners, be included in a formation or limited partnership agreement/addendum. Language in that clause should include notation of relevant and recognised conflict of interest issues at the onset and then mechanisms to deal with any unforeseen conflicts that would arise later. A simple, yet sample clause could read as follows:

"General Partners are held to any and all statutory duty of loyalty issues as they pertain to the operation of the partnership. All known conflict of interest issues must be detailed at the formation of the partnership and it is the duty of any and all potential partners to fully disclose their conflicts to the other partners so that a fully and complete waiver, if so chosen, can be made in a fully informed manner.

Concerning future partners, either limited or general, that chose to join the partnership would be under an affirmative obligation to disclose any and all potential conflicts prior to joining the partnership.

If future conflicts of interest arise in conduct or the pursuit of the partnership enterprise the partners would be under an affirmative duty to disclose the conflict of interest at the earliest moment to allow for the other partners to react and make informed decisions on the manner.

In the case of limited partners, it is understood by all partners, general and otherwise that limited partners are not held to the same level of fiduciary responsibility as general partners, however in the maintenance and continuation of this partnership enterprise it would be prudent for all partners to know of potential conflicts and be allowed to make a fully informed decision as to the admittance or contribution of the limited partner."

\footnotetext{
${ }^{40}$ Courtney, Kirkland \& Viguerie (1997).

${ }^{41}$ Feeley v. NHAOCG, LLC, 62 A.3d 649, 662 (Del. Ch. 2012) (citing Cantor Fitzgerald, L.P. v. Cantor, No. 16297, 2000 WL 307370, at *22 (Del. Ch. Mar. 13, 2000) and Ribstein (2004).
} 


\section{Conclusion}

The bottom line for counselling clients in their formation or involvement in a general or limited partnership is to making sure their interests are protected and fully documented. Counselling clients includes managing expectations and being able to clearly see potential issues that clients would not see as they may be blinded by altruism, false faith or unreasonable expectations. As stated above the creating of partnership agreement is helpful in minimizing and managing risk for the partners. Within that agreement, a clause specifically dealing with duty of loyalty issues needs special attention. In modern business operations it is becoming common place for partners to have several business enterprises and as such those enterprises pose the risk of conflicting with the operation and promotion of each other. Additionally, partners are increasingly interested in limiting liability and responsibility while also maximizing their options. This reality creates the perfect environment for potential duty of loyalty transgressions. Common happenstance duty of loyalty issues such as self-interested transactions, competing interests and others will be at issue the more compound and complex the interests of the individual partners' extra-curricular activities are at play. It should be reunderlined that the power of parties to contract freely should not be impeded or second-guessed by courts, the legislature or the model provisions such as the Revised Uniform Partnership Act. ${ }^{42}$ To do so would cause a chilling effect and "trade and commerce could not thrive if freely made agreements were not normally carried out". ${ }^{43}$ Additionally the need for trial and error in the contracting and partnership agreements lead to a stronger and more educated plans of action in the future. ${ }^{44}$ But it is exactly that philosophy that would encourage legal practitioners to push potential partnership seekers towards complete disclosure and understanding on potential hazards that may arise in the future. As stated above fiduciary duties such as loyalty and care cannot be fully eliminated but may be regulated by agreement, especially in limited partnerships. ${ }^{45}$ But understanding what a partner may or may not do in the future may also save the other partner the headache of associating with the potential hazard in the first place.

\section{References}

Bernstein, D.E., (2008). 'Freedom of Contract' in: David S. Tanenhaus (ed.) Encyclopedia of the Supreme Court of the United States, George Mason University Law and Economics Research Paper Series, George Mason University School of Law, (0851). Available at https://www.law.gmu.edu/assets/files/publications/working_pape rs/08-51\%20Freedom\%20of\%20Contract.pdf.

BSA Mull, No. 310989, at*10 (applying Michigan shareholder oppression law to assist the court in understanding the LLCA's definition of "wilfully unfair and oppressive

\footnotetext{
${ }^{42}$ See Ribstein (2004).

${ }^{43}$ Younkins (2000). See also Postrel (1999).

${ }^{44}$ Weidner \& Larson (1993).

${ }^{45}$ Lewis (2013).
} 
conduct.") Available at https://www.ddc-law.com/blog/fiduciary-duties-owed-byminority-members-of-llcs/

Clarkson, K.W., Miller, L.R. \& F.B. Cross (2015). Business Law - Text and Cases, Legal, Ethical, Global and Corporate Environment, 13th ed. Stanford, Ct: SouthWestern Cengage Learning.

Courtney, H., Kirkland, J. \& P. Viguerie (1997). 'Strategy Under Uncertainty; in Harvard Business Review, November-December Issue. Available at https://hbr.org/1997/11/ strategy-under-uncertainty

Crane, J.A. \& A.R. Bromberg (1968). Law of Partnership. St. Paul, Minn.: West Publishing Company.

Fiduciary Duties in Partnerships, NOLO Legal Encyclopaedia, Legal Topics, Business Formations:https://www.nolo.com/legal-encyclopedia/fiduciary-duties-partnerships. html

Frances, H., 'Michigan Business Partnership Laws' at Legal Zoom, available at https://in fo.legalzoom.com/michigan-business-partnership-laws-22715.html,

Fried Frank (2016). 'Court of Chancery Confirms that Limited Partnership Agreements can Eliminate All General Partner Fiduciary Duties With Respect to Affiliated Transactions - Dieckman v. Regency' in FriedFrank.com, M\&A Briefing, available at https://info.legalzoom.com/michigan-business-partnership-laws-22715.html

Law Depot, Free Partnership Agreement, Create Your Partnership Agreement-Place of Business: Michigan, available at https://www.lawdepot.com/contracts/partner shipagreement/?loc=US\#.WytppqczYdU.

Lewis, W.A., (2013). 'Waiving Fiduciary Duties in Delaware Limited Partnerships and Limited Liability Companies, in Fordham Law Review, 82(2):1017-1051.

Mallor, J.P., Barnes, A.J., Langvardt, A.W., Prenkert, J.D. \& M.A. McCrory (2016). Business Law-The Ethical, Global and E-commerce Environment, $16^{\text {th }}$ ed. New York, NY: McGraw-Hill Education.

Mantese, G. \& I. Williamson (2014). 'Fiduciary Duty in Business Litigation', in Mich. Bar Journal August 2014: 30-33. Available at https://www.michbar.org/file/journal/ pdf/pdf4article2418.pdf

Mayer, D., Warner, D.M., Siedel, G.J., Lieberman, J.K. \& A.R. Martina (2012). The Law, Corporate Finance, and Management, V1.0, 2012 Books, Creative Commons, Section 11.2, referencing Creation of an Express Partnership, Creation in General. Available at https://2012books.lardbucket.org/books/the-law-corporate-finance-andmanagement/s14-02-partnership-formation.html

Postrel, V. (1999). The Future and its Enemies, The Growing Conflict Over Creativity, Enterprise and Progress, New York, NY: Simon \& Schuster Inc. Touchstone.

Reid, B. (2014). 'Good Faith and Fair Dealing in Contract Law Does Not Impose Abstract Morality' in Huff Post available at https://www.huffingtonpost.com/br ad-reid/goodfaith-and-fair-deali_b_5551088.html

Ribstein, L.E. (2004). 'Fiduciary Duties and Limited Partnership Agreements' in Suffolk University Law Review, XXXVII: 927-965.

Weidner, D.J. \& J.W. Larson (1993). 'The Revised Uniform Partnership Act: The Reporters' Overview' in the Business Lawyer 49(1): 1-44. JSTOR, www.jstor.org/ stable/40687453

Younkins, E. (2000). 'Freedom to Contract' in Liberty Free Press. Available at http:// www.quebecoislibre.org/younkins $25 . \mathrm{html}$. 


\section{Cases}

Allen v. El Paso Pipeline GP Co., L.L.C., C.A. No. 7520-VCL (Del. Ch. May 19 2014) (Laster, V.C.)

Diechman v. Regency, GP LP, et al., No. 208, 2016 (Del. Jan. 20, 2017) at Potter, Anderson and Corroon, LLC, Your Delaware Advantage, Delaware Law Updates, available at http://www.potteranderson.com/delawarecase-Dieckman-v-Regency-120-17.html.

Feeley v. NHAOCG, LLC, 62 A.3d 649, 664 (Del. Ch. 2012) (citing Arnold v. Soc'y for Savs. Bancorp, Inc. 678 A.2d 533, 541-42 (Del. 1996).

Feeley v. NHAOCG, LLC, 62 A.3d 649, 662 (Del. Ch. 2012) (citing Cantor Fitzgerald, L.P. v. Cantor, No. 16297, 2000 WL 307370, at *22 (Del. Ch. Mar. 13, 2000)).

Gotham Partners, L.P. v. Hallwood Realty Partners, L.P., 817 A.2d 160, 167 (Del. 2002).

\section{Legislation}

Maryland Code: Corporations and Associations

Michigan Revised Uniform Limited Partnership Act, MCL Act 213 of 1982

Michigan Uniform Partnership Act, MCL Act 72 of 1917

Uniform Partnership Act.

Revised Uniform Partnership Act 